\title{
Application of a Guided Inquiry Model to Improve the Learning Outcomes of Class XI Physics Students
}

\author{
Vina Serevina $^{1}$, Nada Yolanda ${ }^{2}$, Virgiana Tinura $^{3}$ \\ Physics Education Study Program, State University of Jakarta, Indonesia ${ }^{1,2,3}$ \\ \{Vina.serevina77@gmail.com ${ }^{1}$ \}
}

\begin{abstract}
This study aimed to determine the application of guided inquiry learning models to improve student learning outcomes. The research method used classroom action research, which was conducted in two cycles, where each cycle consisted of planning, implementation, observation, and reflection. The minimum completeness criteria (KKM) indicators of learning outcomes that must be achieved are 70 with affective, cognitive, and psychomotor domains. The results of this study indicate that in the first circle, the average score of student learning outcomes in the affective domain is $68.73 \%$, the cognitive domain is $60.33 \%$, and the psychomotor domain is $70.17 \%$. While the average score in the second circle of the affective domain is $72.33 \%$, the cognitive domain is $78.23 \%$, and the psychomotor domain is $76.61 \%$. Based on these results, it can be concluded that the application of a guided inquiry learning model can improve student learning outcomes.
\end{abstract}

Keywords: Guided Inquiry Learning Model, Learning Outcomes

\section{Introduction}

\subsection{Background Issues}

Education has a very important role in preparing qualified human resources and able to master science and technology. Science is an essential aspect of life-related to demands, challenges, and competition in the era of globalization going forward. Physics is a science in which studying natural phenomena or natural phenomena and all the interactions that accompany them. Physics always develops and has an essential role in improving the quality of education, especially in preparing quality students, namely humans who can think critically, logically, initiative, and creatively. Therefore, it is necessary to provide further attention to physics teaching at every level of education, especially in high school education.

Observations were carried out at 42 Jakarta Public High School, the implementation of physics learning in class XI MIPA, which had the minimum completeness criteria (KKM) of the school, namely 70 . The score showed the minimum points to be achieved by students in each domain (Affective, Psychomotor, and Cognitive).

In principle learning is doing, there is no learning if there is no activity. That is why an action is a fundamental principle in teaching and learning interactions. So from that, we need a learning model that can emphasize student learning activities to the maximum to find and find so that student learning outcomes can increase. Guided inquiry learning models are chosen 
which can make students more active in learning so that learning outcomes can improve. Guided inquiry learning models are chosen, which can make students more engaged in learning so that learning outcomes can increase.

Inquiry learning models emphasize the maximum activity of students to look for and find; students are directed to look for and find their answers from a question or problem, meaning the teacher as a facilitator and motivator, and develop the ability to think systematically, logically, and critically. The inquiry learning model emphasizes how students find out for themselves the answer to a given problem. Student learning is enjoyable because it is different from previous learning activities, which only get an explanation using the lecture method, and also students will better understand the concept of heat transfer carried out by practical exercises and finding the concept itself. Therefore, students will be interested in participating in learning activities and understand the material presented so that it will influence the improvement of student learning outcomes. This is following the research, which reveals that inquiry-based learning is very useful in science learning, which refers to discoveries according to the nature of science learning [1].

\subsection{Formulation of the problem}

Does the application of a guided inquiry learning model improve student learning outcomes on XI grade physics subjects at 42 Public High School, Jakarta?

\subsection{Research Purpose}

It was knowing that the implementation of a guided inquiry learning models could improve student learning outcomes in class XI physics subjects at 42 Jakarta Public High School.

\section{Theory}

\subsection{Learning Outcomes}

To provide an understanding of learning outcomes, it will be described first in terms of language. This definition consists of two words of learning and results. The meaning of findings has several implications: 1) Something held by a business, 2) Income, acquisition, fruit. While learning is a change in behavior or response caused by experience.

The meaning of learning is a change in behavior in the individual thanks to the interaction between one individual and another individual and between individuals and the environment [2]. Learning is (1) bring to change, (2) that the change occurred because of a deliberate effort [3]. From the above definitions, the expert can see the term change which means that after someone has learned it will changes

Learning outcomes is a change in behavior in a person that can be observed and measured forms of knowledge, attitudes, and skills [4]. These changes can be interpreted as an increase and development that is better than before and who doesn't know to know. Learning outcomes can be interpreted as the maximum results achieved by students after experiencing the learning process in learning a particular subject matter. Learning outcomes are not absolute in the form 
of values, but can be in the form of changes or improvements in attitudes, habits, knowledge, tenacity, fortitude, reasoning, discipline, skills, and so on that lead to positive change.

\subsection{Factors that influence learning outcomes}

The learning outcomes achieved by students are influenced by two factors, namely, internal factors that come from these students and external factors that originate from outside the students' self [5]. In addition to the ability factor of students, there are other factors such as motivation to learn, interest, and attention. Even the factors where a teacher chooses an exciting and appropriate learning model can affect the success of students in learning whether students will more easily capture the material presented and create students who are active or not.

\subsection{Guided inquiry learning model}

Inquiry-based learning can stimulate students' desire to understand concepts, motivate them to continue their work until they find answers to a problem, and give students real and active experiences [6]. Students are also expected to talk initiatives to solve problems, make decisions, and acquire skills. Therefore, inquiry enables the integration of various disciplines.

Furthermore, inquiry-based learning process teachers can facilitate students in full or only a small part through worksheets or another instruction so students can find the problem up to the answer to these problems. That is what he thinks the guided inquiry is very important to apply [7].

Inquiry-based learning consists of three types, namely guided inquiry, free inquiry, and modified free inquiry [8]. The difference between the three lies in the learning activities carried out. Guided inquiry, the implementation of learning is carried out on the instruction of the teacher in the form of core questions to direct students to the expected conclusion point, while in free inquiry, students learn to formulate their problems, conduct their investigations [8].

Serevina, Vina, Wawan Andriana, and Anan Fernandianto improve the creative thinking ability of class X students' public high school 59 Jakarta through guided inquiry learning model [11]. It can be concluded that students' creative thinking skills can be improved through guided inquiry learning models.

\subsection{Temperature and Heat}

Try to observe and feel about the difference in heat day and night. On a hot day, you certainly feel the air is warm. At that time, I usually said that the air temperature is so high. But at night we will feel colder than hot, which then at that time the temperature is said to be low. From the statement, we can conclude that temperature is the state of heat or coldness of an object.

Temperature can be measured by a device called thermometer. Properties measured to express temperature are called thermometric properties. The unit of temperature is the degree. Heat is an energy transfer that occurs from objects with a higher temperature to lower temperature objects. Heat can result in changes in the temperature or appearance of a substance. Heat is one of energy so that it can move from one system to another due to temperature differences. Otherwise, every time there is a temperature difference between the two systems, there will be a change in heat. For example, the ice that put in a glass of hot 
water will be melt and the water will be cool. Because there is a temperature difference between ice and water so the hot water releases some of the heat so that the temperature drops and ice receives the heat so that the temperature rises (melts). Heat flows by itself from an object with a higher temperature to another object with a lower temperature. In the $18^{\text {th }}$ century, it was illustrated the flow of heat as a movement of fluid substances called calories. When you boil water, you need heat to raise the water temperature until the water is boiled. How much heat does water need to raise the temperature to the desired temperature? Inductively, the greater the temperature of an object improves, the greater the heat absorbed. Also, the heat absorbed by objects depends on the mass of the object and the constitution material. Mathematically can be seen in equation 1 .

$$
Q=m x c x \Delta T
$$

Information:

$Q$ : heat absorbed/released by objects $(J)$;

$m$ : the mass of objects $(\mathrm{kg})$;

$c$ : heat type of objects $\left(\mathrm{J} / \mathrm{kg}^{\circ} \mathrm{C}\right)$;

$\Delta T$ : temperature change $\left({ }^{\circ} \mathrm{C}\right)$.

\subsection{Heat Type}

Heat type of matter (substance) shows the amount of heat needed by 1 kilogram of substance to improve its temperature by a unit of temperature $\left({ }^{\circ} \mathrm{C}\right)$. This means that each object (substance) required different heat even though to improve the same temperature and the same mass. Heat types of several substances can be seen in the following table.

\subsection{Heat Capacity}

Heat capacity is the amount of energy given in the form of heat to improve the temperature of an object by one degree. In the International Unit System, the heat capacity unit is $\mathrm{JK}^{-1}$. However, because in Indonesia, temperatures commonly stated on the Celsius scale, then the heat capacity unit used in this book is $\mathrm{J} /{ }^{\circ} \mathrm{C}$. heat capacity can be formulated using equation 2.

$$
Q=C \times \Delta T
$$

Information:

$Q$ : heat absorbed/released $(J)$;

$C$ : object heat capacity $\left(\mathrm{J} /{ }^{\circ} \mathrm{C}\right)$;

$\Delta T$ : temperature change of the object $\left({ }^{\circ} \mathrm{C}\right)$.

If the equation of heat capacity is compared with the type of heat equation, then the equation will be equation 3 .

$$
C=m \times c
$$

Information:

$C$ : object heat capacity $\left(\mathrm{J} /{ }^{\circ} \mathrm{C}\right)$; 
$m:$ of objects $(\mathrm{kg})$;

$c$ : heat type of the object $\left(\mathrm{J} / \mathrm{kg}{ }^{\circ} \mathrm{C}\right)$.

\section{Methodology}

This type of research is class action research (CAR), which is held in even semester. Classroom action research is a reflection of learning activities in the form of an action, which is deliberately raised and occurs in a shared class [9]. CAR as the process of studying learning problems in the classroom through self-reflection in an effort to solve these problems by carrying out various planned actions in real situations and analyzing each influence of these treatments [10]. Based on the definition above, it can be interpreted that classroom action research is an action that is raised in the classroom to improve the practice of learning by taking planned actions and analyzing each influence of the treatment.

There are several patterns of CAR implementation, which means "the pattern is the method or technique of implementing CAR that can be used as a reference in the implementation of CAR according to the CAR model chosen by considering the conditions of the researcher and available data sources. Various patterns of CAR implementation, namely: CAR pattern teacher research, collaborative pattern CAR, and integrated CAR simultaneous patterns" [10].

In this study, the type of action research used is a collaborative classroom action research, namely collaboration or collaboration between teachers and researchers. Researchers and teachers prepare evaluation instruments, get involved in learning and in planning actions to be carried out, and carry out learning in accordance with the scenario that has been prepared together. This study discusses two cycles in which each cycle consists of 2 meetings.

The instruments for the pre-test and post-test used five essay questions. The material of the test is temperature and heat. And sampling method by purposive sampling method.

\subsection{First cycle}

Plan. The planning stage is done by making data collection instruments such as observations, gathering students on student worksheets. Make an implementation plan following the guided inquiry learning model on temperature and heat material.

Implementation. During implementation, researchers used a guided inquiry learning model with the following steps:

1) Orientation. Listening activities such as listening to the motivation of the teacher, emotional activities such as taking interest and building curiosity, and mental activities such as remembering and building relationships between knowledge that has been learned and new knowledge

2) Exploration. Motor and visual activities such as observing, reading, observing an object, mental activities such as thinking, seeing a relationship, and making decisions, oral and listening activities such as asking questions and discussing, and writing activities such as writing the findings of a concept.

3) Concept Formation. Visual activities such as observing exploration results, mental activities such as analyzing, seeing relationships, solving problems, and decisions, 
and writing activities such as writing the results of analysis and conclusions based on relationships between concepts.

4) Application. Mental activities such as analyzing concepts to be applied in certain situations, as well as writing activities such as writing the results of analysis and conclusions obtained in training.

5) Closure

Mental activities such as thinking and reflecting concepts learned, oral activities such as expressing opinions, expressing a fact or principle, asking questions, and giving advice, listening activities such as listening to other people's opinions, writing activities such as writing the results of knowledge that has been learned, and drawing activities like drawing and graphics.

The implementation documentation can be seen in Figure 1.

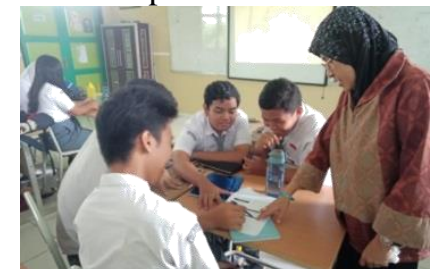

a)

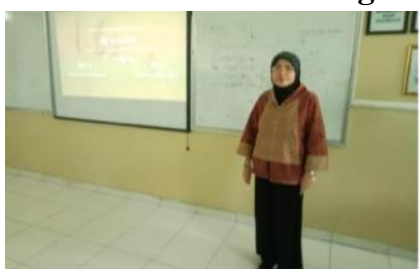

b)

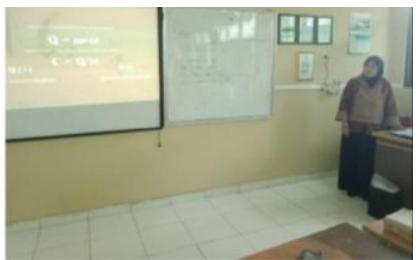

c)

Fig. 1. a) Students discuss when learning, b) Delivering Learning Material, c) Class activities discussion on learning.

Observation. Observations were carried out collaboratively between teachers, students, and lecturers conducted at that phase. Taking documentation during the first cycle is done, as well as recording data for field notes from student responses to all events that occur in learning.

Reflection. The researcher monitors and evaluates the observations obtained during the first cycle and then makes an interpretation. All observations were reviewed together by teachers, students, and lecturers. The results of these reflections are used as considerations in solving existing problems and planning the second cycle if there are still shortcomings in cycle I. The documentation of evaluation after learning activities can be seen in Figure 2.

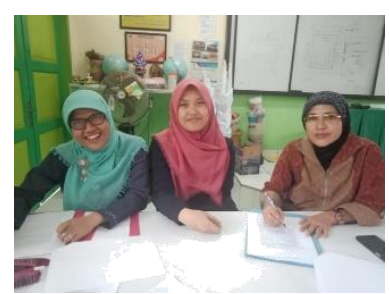

Fig. 2. Evaluation after learning activities.

\subsection{Second cycle}

Plan. The plan in the second cycle is a reflection of a cycle I. At this stage, the teacher motivates students and is directly involved in learning with a guided inquiry model, by giving 
problems and making students find their answers so that activities occur in the class could make students want to actively participate in the learning process.

Implementation. The implementation uses a guided inquiry learning model in the second cycle. During implementation, researchers used a guided inquiry learning model with the following steps:

\section{1) Orientation}

Given, put curiosity towards the lesson, and build a relationship between knowledge that has been learned with new knowledge.

2) Exploration

Asks questions and discusses based on the knowledge that has been obtained and new knowledge on a concept learned by the concept.

3) Concept Formation

Writes the results of analysis and conclusions based on relationships between concepts, which are derived from previous knowledge and newly acquired

4) Application

Analyzes the concepts to be applied in solving certain problems, and writes the results of the analysis and conclusions obtained in the exercise.

5) Closure

Closure thinks and reflects on the concepts learned, expresses opinions, expresses a fact or principle, asks questions, and gives suggestions, also listens to the opinions of others.

The implementation documentation can be seen in Figure 3.

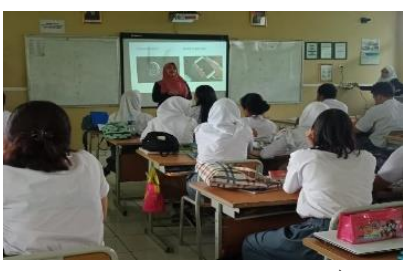

a)

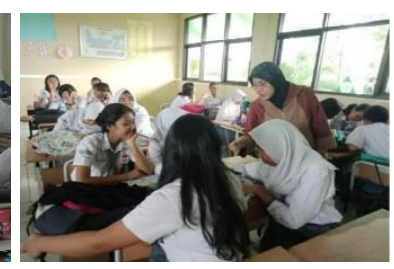

b)

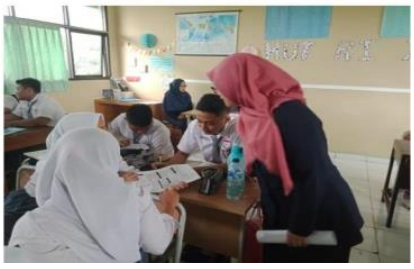

c)

Fig. 3. a) Students observe the problem given in learning activities, b,c) Students discuss groups.

Observation. Observation in the second cycle records all new findings that occur during the teaching and learning process. Data is then processed and analyzed. All components of both the teacher, students are truly teaching in order to create a conducive classroom atmosphere so that learning using a guided inquiry learning model can be carried out better than the first cycle. The documentation can be seen in Figure 4.

Reflection. Indicator of success has been achieved, the average score of student learning outcomes (cognitive, affective, and psychomotor domains) has exceeded 70, so the second cycle is stopped. The evaluation documentation can be seen in Figure 5. 


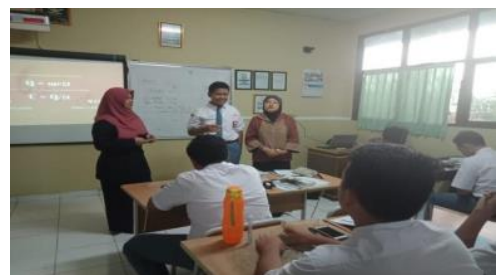

Fig. 4. Students try teaching aids in the form of thermometers.

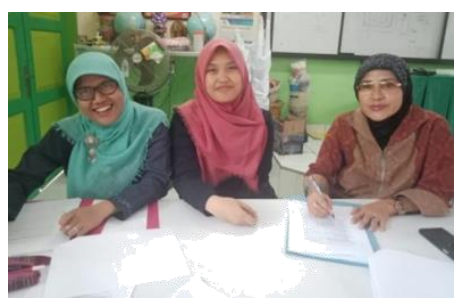

Fig. 5. Evaluation in cycle II.

\section{Results and Discussion}

After conducting this class action research with two cycles, data was obtained based on the data triangulation method. This research used a cycle design that will stop when the achievement indicators have been reached. In this case, the average student learning outcomes in the three domains have reached more than 70. This study was conducted in October 2018 (Cycle I) and November 2018 (Cycle II) IN 42 Jakarta High School, located at Halim Perdana Kusuma, East Jakarta. The object of the research is students from class XI MIPA 2, 2017/2018 academic year.

In this study, the results of research on temperature and heat material with action tests obtained student learning outcomes. This research was conducted in two cycles, where each cycle was carried out reflection aimed at correcting steps that were not appropriate in the learning model chosen to obtain data that truly illustrated the success of the method. The results obtained in the table listed in Table 1 and the diagram of outcomes can be seen in Figure 6.

\section{Diagram Learning Outcomes in Physics Learning}

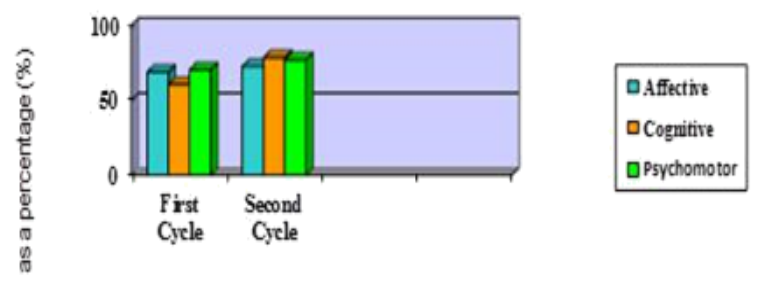

Fig. 6. Graph of Student Learning Activities.

Table 1. Data on student learning outcomes from cycle I and II.

\begin{tabular}{ccc}
\hline Aspect & Cycle I & Cycle II \\
\hline Affective & 68,73 & 72,33 \\
Cognitive & 60,33 & 78,23 \\
Psychomotor & 70,17 & 76,61 \\
\hline
\end{tabular}




\section{Documentation}

Learning activities in the classroom have improved both from the aspect of teachers and students who are more active in learning activities evidenced by the improvement in learning outcomes with the guided inquiry learning model that has been carried out. The learning activities documentation can be seen in Figure 7.
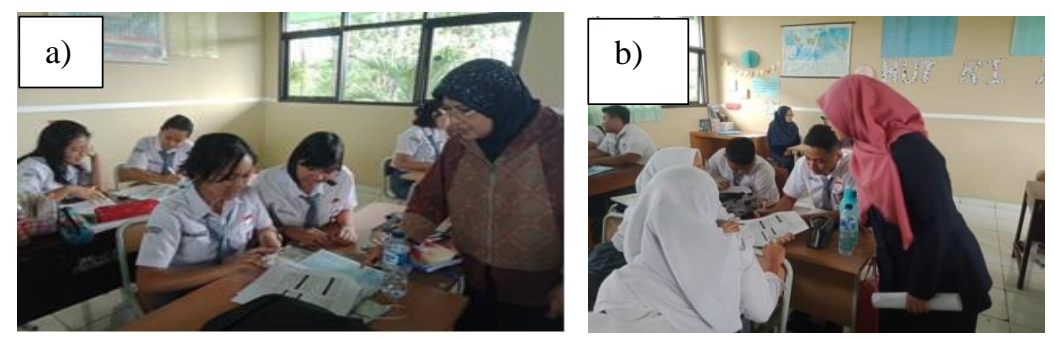

Fig. 7. a) Students ask about the subject matter, b) Students actively ask about learning activities.

The results of this study indicate that the average score of student learning outcomes in the affective domain of the first cycle is $68.73 \%$, the cognitive domain of the first cycle is $60.33 \%$, and the psychomotor domain of the first cycle is $70.17 \%$. While the average score of affective domain student learning outcomes from the second cycle $72.33 \%$, the cognitive domain of the second cycle $78.23 \%$, and the psychomotor domain of the second cycle $76.61 \%$. Where the minimum completeness criteria (KKM) from the school that students must meet are 70 have been achieved.

\section{Conclusion}

Based on the results described, from this classroom action research, it can be concluded that the application of a guided inquiry learning model can improve student learning outcomes.

\section{References}

[1] Rustaman, N. Y.: Perkembangan Penelitian Pembelajaran Inkuiri Dalam Pendidikan Sains. Research Journal. FMIPA UPI (2005)

[2] Usman, M. U.: Menjadi Guru Profesional. Remaja Rosdakarya (2000)

[3] Subrata, S. S.: Psikologi Pendidikan. Raja Grafindo Persada (1995)

[4] Hamalik, O.: Media Pendidikan. Alumni (2007)

[5] Sudjana, N.: Metode Statistika. PT. Tarsito Bandung (2005)

[6] Kunandar.: Guru Profesional Implementasi Kurikulum Tingkat Satuan Pendidikan (KTSP) dan Sukses dalam Sertifikasi Guru. Raja Grafindo Persada (2007)

[7] Paidi.: Peningkatan Scientific Skill Siswa Melalui Implementasi Metode Guided Inquiry pada Pembelajaran Biologi di SMAN 1 Sleman (2007)

[8] Hanafiah, N., Suhana, C.: Konsep Strategi dan Pembelajaran. PT Refika Aditama (2012)

[9] Suharsini, A., Supardi S.: Penelitian Tindakan Kelas. BumiAksara (2009) 
[10] Sanjaya, D. H. W.: Penelitian Tindakan Kelas. Kencana Prenada Media Group (2009)

[11] Serevina, V., Andriana, W., Fernandianto, A.: Improving Creative Thinking Ability of Class X Students Public High School 59 Jakarta Through Guided Inquiry Learning Model. American Journal of Educational Research (2017) 